\title{
Cidades traduzidas: Moscou e São Petersburgo
}

\author{
Edelcio Americo ${ }^{1}$
}

Resumo: O objetivo do presente trabalho é traz̧er duas traduções do russo para o português: Notas petersburguesas, escrita por Nikolai Gogol em 1836, e Dois caráteres, irmão e irmã, de 1841, escrita por Mikhail Zagóskin.

Palavras-chave: tradução literária; literatura russa.

O objetivo do presente trabalho é trazer duas traduções do russo para o português: Notas petersburguesas, escritas por Nikolai Gogol em 1836, e Dois caráteres, irmão e irmã, de 1841, escrita por Mikhail Zagóskin. Para a contextualização das obras supramencionadas, faço uma breve introdução do conceito de texto de cidade: a tradução de lugares e da memória cultural em texto, cuja decodificação nos oferece enorme ajuda na compreensão das obras artísticas.

A oposição Moscou e São Petersburgo tornou-se fato da história russa desde o surgimento da nova capital, às margens do rio Nevá, por imposição do Imperador Pedro, o Grande, em 1703, e atingiu todos os segmentos do desenvolvimento histórico-cultural da Rússia. Na cultura russa, desde então, começaram a se formar divergências essenciais entre a nova e a velha capital, que representavam dois conceitos políticos e fixavam dois tipos culturais.

O conceito de "texto" em relação à cidade, mais precisamente sobre São Petersburgo, foi adotado inicialmente por Vladimir Toporov, em 1973, ${ }^{2}$ rendendo, posteriormente, inúmeros trabalhos e gozando de grande popularidade.

1 Doutor em Letras - Russo pela Faculdade de Filosofia, Letras e Ciências Humanas da Universidade de São Paulo. Contato: americo.edelcio@gmail.com.

2 TOPOROV, Vladimir. Sobre a estrutura do romance de Dostoiévski em relação aos esquemas arcaicos do pensamento mitológico (O struktúre romana Dostoiévskogo v sviaí s arkhaítcheskimi skhiémami mifologuítcheskogo mychliénia). In: Mito, ritual, símbolo, imagem (Mif, ritual, símvol, óbraそ). Moscou: Progress, 1995, p. 193-258. 
Para compreender como uma cidade pode ser representada em um texto é preciso definir qual é a sua imagem na memória e no inconsciente popular. No caso da literatura, o texto de uma cidade seria a sua imagem cultural expressa em várias obras de diferentes autores e dotada de uma certa solidez semântica.

O texto de Moscou não pode ser plenamente compreendido sem levar em consideração o texto de São Petersburgo e vice-versa. Petersburgo, em relação à Moscou, é como uma árvore sem raiz. A sua raiz é Moscou, por representar o contexto histórico cultural que faltava para a nova capital. De certa forma, São Petersburgo "cresceu" de dentro de Moscou, é o seu fruto e a sua continuação:

Mas, essencialmente, os fenômenos de Petersburgo e Moscou no contexto geral da Rússia, em suas diferentes fases não excluíam nem uma e nem outra, as cidades se completavam, apoiavam e intercambiavam. As diferenças entre as duas capitais decorriam não apenas de uma necessidade histórica, mas daquela providencialidade que necessitava dos dois tipos, das duas estratégias, dos dois caminhos de sua existência. ${ }^{3}$

Desse modo, para que o "texto de Petersburgo" exista, há a necessidade da contraposição com a antiga capital:

Moscou, nesse caso, tem que ser considerada o membro líder da comparação, pois a imagem de Petersburgo no "texto de São Petersburgo" se forma, em muito, como um anti-modelo mitologizado de Moscou. Se trata da característica mais importante, espacial, que combina os traços de diacronia e de sincronia e que possui uma saída para as outras esferas (inclusive para a esfera ética). O espaço de Moscou (corpo) contrapõe-se a Petersburgo e seu espaço como algo orgânico, quase natural (daí a abundância das metáforas vegetais nas descrições de Moscou), que apareceu por si mesmo sem vontade de ninguém, sem planos, sem intervenção em oposição ao não-orgânico, artificial, somente "cultural", chamado à vida por uma vontade violenta, de acordo com um esquema pensado, um plano, uma regra. Essa é a origem de uma concretude especial e de uma realidade terrestre de Moscou, diferente da Petersburgo abstrata, exagerada, fantasmagórica, "inventada". ${ }^{4}$

Assim, por meio da constante correlação entre as duas capitais, surgiram as principais características que diferem uma cidade da outra. Obviamente, seria

3 TOPOROV, Vladímir, São Petersburgo e "o texto de Petersburgo" da literatura russa. In: O texto de Petersburgo da literatura russa. São Petersburgo: 2003, p. 22-23.

4 Idem, p. 20-21. 
incorreto dizer que, nessa relação, a Moscou foram atribuídas apenas qualidades positivas, enquanto São Petersburgo recebeu só negativas. Ambas as cidades foram marcadas tanto positiva quanto negativamente:

Justamente com base nessas ideias, em um determinado contexto criou-se, já há quase dois séculos, a contraposição atual entre Petersburgo e Moscou. No geral, a demarcação dessas capitais formava-se conforme um de dois esquemas possíveis. Segundo um deles, a Petersburgo desalmada, burocrática, militar, oficial, regular de maneira antinatural, abstrata, desaconchegante, jacente, não russa, contrapunha-se à Moscou cordial, familiar, íntima, patriarcal, aconchegante, "materialmente real", natural, russa. Segundo o outro esquema, Petersburgo, como uma cidade civilizada, cultural, organizada de maneira planejada, correta e lógica, harmoniosa e europeia, contrapunha-se a Moscou que parecia uma aldeia caótica, desordenada, semi-asiática, contrária à lógica. ${ }^{5}$

Além disso, desde os tempos mais remotos, o homem relacionava os lugares que conhecia a deuses ou espíritos locais. Nessa personificação, a Terra sempre foi ligada à imagem feminina, materna. Em muitas culturas existem divindades femininas que personificam a Mãe-Terra e, provavelmente, a mais conhecida delas seja a deusa grega Gaia. Não é por acaso que em muitas línguas as palavras terra e país pertencem ao gênero feminino. Embora em russo a palavra cidade, górod, seja do gênero masculino, muitos dos topônimos das cidades russas são do gênero feminino, basta lembrar Moscou (em russo, Moskvvâ), Samara, etc. Entre os países, muitos também pertencem ao gênero feminino: Rússia, Inglaterra, Alemanha, França e assim por diante.

Em geral, Moscou costuma ser descrita ou como uma senhora (ou viúva), ou como uma moça (noiva, namorada). A imagem de Moscou como uma "velha caseira" surgiu a partir da segunda metade do século XVIII, quando São Petersburgo passou a ser associada à ideia de progresso. Em comparação com a nova capital em crescimento, Moscou começou a ser percebida como "mais arcaica do que era". ${ }^{6}$ Essa ideia foi claramente enunciada por Aleksandr Púchkin, que em Viagem de Moscou para Petersburgo afirma:

5 Idem. P. 16.

6 IUSSÚPOV, K. Diálogo das capitais no movimento histórico (Dialóg stolits v istorítcheskom dvijénii). In: Pro et Contra Moscou - Petersburgo (Pro et Contra Moskvá - Peterburg). Moscou: RGKHI, 2000, p. 10. 
A decadência de Moscou é uma consequência inevitável da elevação de Petersburgo. As duas capitais não podem igualmente florescer dentro do mesmo Estado, assim como dois corações não coexistem no corpo humano. ${ }^{7}$

A inversão de características entre as cidades novamente aconteceu após a transferência da capital, dessa vez de Petrogrado, como era chamada São Petersburgo entre os anos de 1914 e 1924, para Moscou. Aliás, Moscou nunca mudou de nome, aqui podemos destacar mais uma oposição: transformação x estabilidade.

Quando em 1919 Moscou volta a ser capital ela adquire traços que antes eram tipicamente petersburgueses: se torna a cidade que carrega a força desumana do poder oficial. A partir de então, é como se as duas cidades trocassem de lugar: dessa vez é Moscou que se transforma em um palco de acontecimentos verdadeiramente fantásticos e diabólicos. Não é por acaso que no romance de Mikhail Bulgákov, Mestre e Margarida (1940), um dos personagens principais, o Diabo, escolhe justamente Moscou para sua aparição quando quer conhecer o novo país soviético e o seu povo.

Moscou torna-se uma cidade contemporânea, que segue as últimas tendências europeias, já São Petersburgo passa a ser vista como uma capital da província russa. São Petersburgo permanece como guardião das tradições e da cultura autenticamente russa, enquanto Moscou se mostra submersa no ecletismo dos estilos.

Apresento abaixo a tradução de dois textos, escritos na primeira metade do século XIX, e dedicados à imagem de Moscou e à sua oposição a então capital, São Petersburgo. Vale ressaltar que o período que compreende o final do século XVIII até o final do século XX foi de intensificação das controversas entre as duas cidades. Uma das consequências inevitáveis da europeização da Rússia iniciada por Pedro, o Grande, foi a questão do caminho que o país deveria seguir: imitar a Europa ou buscar a autenticidade nacional. Nessa discussão, Moscou passou a representar o tradicional e costumeiro, enquanto São Petersburgo se tornou o símbolo do alheio e estrangeiro.

Os textos traduzidos representam apenas uma parte de um volumoso corpo de textos dedicados às relações entre Moscou e Petersburgo. Aliás, são poucos os textos que mencionam somente Moscou, sem mencionar a capital do Norte. Esse fato serve como mais uma prova de que os textos das duas capitais não podem ser analisados separadamente por serem, na verdade, dois lados de uma mesma cultura, opostos, porém interligados.

7 IUSSÚPOV, K. Diálogo das capitais no movimento histórico (Dialóg stolits v istorítcheskom dvijénii). In: Pro et Contra Moscou - Petersburgo (Pro et Contra Moskvá - Peterburg). Moscou: RGKHI, 2000, p. 11. 
O ensaio Notas petersburguesas, de 1836, escrito por Nikolai Gógol (18091852) é um dos textos que melhor representa o bicentrismo na cultura russa, bem como o caráter feminino de Moscou e masculino de São Petersburgo. Nele, temos uma das melhores definições para o embate cultural estabelecido na famosa frase: “a Rússia precisa de Moscou; Petersburgo precisa da Rússia”.

O ensaio de Mikhail Zagóskin (1789-1852) Dois caráteres. Irmão e irmãa, de 1841, retoma vários dos temas inicialmente abordados por Gógol, entre eles os traços femininos que a cidade de Moscou adquiriu na cultura russa em oposição ao caráter masculino de São Petersburgo.

\section{Notas petersburguesas de $1836^{8}$ (Nikolai Gógol, excerto)}

...Vejam só onde foi parar a capital russa, no fim do mundo! Como é estranho esse povo russo: a capital era em Kiev, lá era quente demais, fazia pouco frio; a capital mudou para Moscou, não, lá também fazia pouco frio: que Deus nos dê São Petersburgo! A capital russa aprontará uma daquelas ao se avizinhar do Polo Norte. Digo isso pois ela está salivando para ver os ursos brancos de perto. "Correr para setecentas verstas longe da mãezinha! Mas que ágil!”, diz o povo moscovita, apertando os olhos para o lado finlandês. Em compensação, que barbárie que há entre a mãezinha e o filhinho! Que vista, que natureza! O ar repleto de neblina; na terra pálida, cinza e verde, cepos queimados, floresta de abetos, barrancos... Ainda bem que a estrada voa como uma flecha e as tróicas tilintantes o levarão embora em um instante. E que diferença, mas que diferença entre esses dois! Ela ainda é uma barba russa, ele já é um alemão asseado. Como se estendeu, como se ampliou a velha Moscou! Como ela está despenteada! Como se juntou, como se retesou o janota Petersburgo! Diante dele há espelhos por todos os lados: aqui está o Nevá, ali o Golfo da Finlândia. Ele tem onde se olhar. É só ver uma pluminha ou sujeirinha, que no mesmo instante segue um piparote. Moscou é uma velha caseira, faz panquecas, olha de longe e escuta histórias sobre o que acontece no mundo sem se levantar das poltronas; Petersburgo é um rapaz desembaraçado, nunca fica em casa, sempre está bem vestido, passeia na fronteira e se enfeita para a Europa, a qual vê, mas não ouve.

Petersburgo se mexe inteiro, das adegas até os sótãos; à meia-noite começa a assar pães franceses que amanhã comerá o povo alemão, e a noite inteira brilha

8 O ensaio Notas petersburguesas de 1836 foi publicado pela primeira vez na revista Sovremiénnik, em 1837, volume VI. 
um de seus olhos, ou o outro; Moscou à noite dorme inteira, e, no dia seguinte, após persignar-se e fazer reverências para todos os lados, sai para vender roscas na feira. Moscou é do gênero feminino; São Petersburgo, masculino. Em Moscou, todas são noivas; em São Petersburgo, todos são noivos. Petersburgo observa grande decência em suas vestimentas, não gosta de cores variadas nem de quaisquer alterações bruscas ou impertinentes da moda; em compensação, Moscou exige que, caso tenha virado moda, que seja como deve ser: se a cintura deve ser comprida, ela a deixa ainda mais comprida; se as lapelas da casaca devem ser grandes, as dela serão como portas de um galpão. Petersburgo é um homem ordenado, um alemão completo, olha para tudo fazendo contas, e, antes de dar uma festa, confere o bolso; Moscou é uma nobre russa, e se ela se diverte, faz isso até cair e não se preocupa se vai gastar mais do que tem no bolso: ela não gosta de meio-termo. Em Moscou todas as revistas, por mais científicas que sejam, terminam com um desenho de moda; as petersburguesas raramente acrescentam desenhos, e, quando adicionam um, quem olha sem estar acostumado pode tomar um susto. As revistas moscovitas falam de Kant, Schelling etc., etc.; nas revistas de São Petersburgo só se fala do público e de boas intenções... Em Moscou, as revistas andam junto com o século, mas as edições saem atrasadas; em Petersburgo, as revistas não andam junto com o século, mas saem em ordem, no tempo previsto. Em Moscou, os literatos perdem dinheiro, em São Petersburgo ganham. Moscou sempre vai de carruagem, enrolada no casaco de pele de urso e, geralmente, para o almoço; Petersburgo, de sobrecasaca de flanela, colocando ambas as mãos nos bolsos, voa a todo vapor para a bolsa ou "para o serviço". Moscou pandega até quatro horas da madrugada e no dia seguinte não se levanta da cama antes de uma e pouco; Petersburgo também farreia até as quatro, porém, no dia seguinte, como se nada tivesse acontecido, apressa-se, com sua sobrecasaca de flanela, para a repartição pública. A Rússia arrasta-se até Moscou com dinheiro no bolso e volta sem nada; já em Petersburgo as pessoas chegam sem dinheiro e saem para qualquer canto do mundo com um capital considerável. A Rússia arrasta-se de kibitk $a^{9}$, pelos barrancos do inverno, até Moscou para vender e comprar, já para São Petersburgo o povo russo vai a pé, no verão, para construir e trabalhar. Moscou é um armazém, empilha as trouxas e cargas e nem se digna a olhar para um vendedor pequeno. Petersburgo dissipou-se em pedacinhos, dividiu-se, expôs-se em lojinhas e mercados e está atrás dos pequenos compradores. Moscou diz: "Se o comprador precisar, ele achará"; Petersburgo empurra as placas para debaixo

9 Kibitka: trenó coberto. 
do seu nariz, cava mais um piso para instalar embaixo uma loja de vinhos e coloca o ponto de cocheiros bem na porta da sua casa. Moscou não olha para os seus moradores e manda mercadorias para toda a Rússia; Petersburgo vende gravatas e luvas para os seus funcionários. Moscou é uma grande galeria de lojas; Petersburgo é um mercado iluminado. A Rússia precisa de Moscou; Petersburgo precisa da Rússia. Em Moscou é difícil encontrar um botão de brasão ${ }^{10}$; em Petersburgo não existe casaca sem botões. Petersburgo gosta de zombar de Moscou, do seu mau gosto, por ela ser desajeitada e deselegante; Moscou cutuca Petersburgo por ele ser um homem venal e não saber falar o russo. Em Petersburgo, na Avenida Niévski, passeiam, às duas horas, pessoas que parecem ter saído das ilustrações de jornais de moda; nas janelas, até as velhas têm cinturas tão finas que chega a ser engraçado; em Moscou, na rua sempre é possível encontrar uma tiazinha com lenço na cabeça e já sem cintura alguma. Eu diria ainda mais algumas coisas, mas... A distância é enorme! ${ }^{11}$

\section{Николай Гоголь}

\section{ПЕТЕРБУРГСКИЕ ЗАПИСКИ 1836 ГОАА.}

...В самом деле, куда забросило русскую столицу -- на край света! Странный народ русский: была столица в Киеве -- здесь слишком тепло, мало холоду; переехала русская столица в Москву -- нет, и тут мало холода: подавай бог Петербург! Выкинет штуку русская столица, если подсоседится к АеАяному полюсу. Я говорю это потому, что у ней слюна катится поглядеть вблизи на белых медведей. «На семьсот верст убежать от матушки! Экой востроногой какой!» -- говорит московский нароА, прищуривая глаз на чухонскую сторону. Зато какая дичь межАу матушкою и сынком! Что это за виды, что за природа! Воздух продернут туманом; на бледной, серо-зеленой земле обгорелые пни, сосны, ельник, кочки... Хорошо еше, что стрелою метящее шоссе Аа русские поющие и звенящие тройки духом пронесут мимо. А какая разница, какая разница между ими Авумя! Она еще Ао сих пор русская борода, а он уже аккуратный немец. Как раскинулась, как расширилась старая Москва! Какая

10 Botão de brasão: botões de casaca que eram uma espécie de cartão de visita tanto dos militares como dos funcionários, e apenas a nobreza com direito ao título hereditário podia utilizá-los.

11 Aqui Gógol cita as palavras de Skalozub, um dos protagonistas da peça Górie ot umá de Aleksandr Griboiédov: Onde é possível encontrar uma capital como Moscou? A distância é enorme. 
она нечесанная! Как сдвинулся, как вытянулся в струнку щеголь Петербург! Перед ним со всех сторон зеркала: там Нева, там Финский залив. Ему есть куда поглядеться. Как только заметит он на себе перышко или пушок, ту ж минуту его щелчком. Москва -- старая домоседка, печет блины, глядит издали и слушает рассказ, не подымаясь с кресе, о том, что делается в свете; Петербург -- разбитной малый, никогда не сидит дома, всегда одет и, охорашиваясь перед Европою, раскцанивается с заморским Аюдом.

Петербург весь шевелится, от погребов до чердака; с полночи начинает печь французские хлебы, которые назавтра все съест немецкий народ, и во всю ночь то один глаз его светится, то Аругой; Москва ночью вся спит, и на Аругой день, перекрестившись и поклонившись на все четыре стороны, выезжает с калачами на рынок. Москва женского рода, Петербург мужеского. В Москве всё невесты, в Петербурге всё женихи. Петербург наблюдает большое приличие в своей одежле, не мюбит пестрых цветов и никаких резких и дерзких отступлений от моды; зато Москва требует, если уж пошло на моду, то чтобы во всей форме была мода: если талия Алинна, то она пускает ее еще Алиннее; если отвороты фрака велики, то у ней, как сарайные Авери. Петербург -- аккуратный человек, совершенный немец, на всё глядит с расчетом и прежле, нежели залумает Аать вечеринку, посмотрит в карман; Москва -- русский Аворянин, и если уж веселится, то веселится до упаду и не заботится о том, что уже хватает больше того, сколько находится в кармане; она не ^юбит средины. В Москве все журналы, как бы учены ни были, но всегда к концу книжки оканчиваются картинкою мод; петербургские редко прицагают картинки; если же приложат, то с непривычки взглянувший может перепугаться. Московские журнацы говорят о Канте, Шем^инге и проч. и проч.; в петербургских журнацах говорят только о публике и благонамеренности... В Москве журналы идут наряду с веком, но опаздывают книжками; в Петербурге журналы нейдут наравне с веком, но выходят аккуратно, в положенное время. В Москве Аитераторы проживаются, в Петербурге наживаются. Москва всегда едет, завернувшись в медвежью шубу, и большею частию на обеА; Петербург в байковом сюртуке, заложив обе руки в карман, Аетит во всю прыть на биржу или «в Аолжность». Москва гуляет до четырех часов ночи и на Аругой Аень не подымется с постели раньше второго часу; Петербург тоже гуляет до четырех часов, но на Аругой день, как ни в чем не бывац, в девять часов спешит в своем байковом сюртуке в присутствие. В Москву тащится Русь с деньгами в кармане и возвращается налегке; в Петербург едут мюди безденежные и разъезжаются во все стороны света с изрядным капиталом. В Москву тащится Русь в зимних кибитках по 
зимним ухабам сбывать и закупать; в Петербург идет русский народ пешком цетнею порою строить и работать. Москва -- кцадовая, она наваливает тюки Аа вьюки, на мелкого продавца и смотреть не хочет; Петербург весь расточился по кусочкам, разделился, разАожился на Аавочки и магазины и цовит мелких покупщиков. Москва говорит: «коли нужно покупщику, сыщет»; Петербург сует вывеску под самый нос, подкапывается под ваш пол с «Ренским погребом» и ставит извозчичью биржу в самые двери вашего дома. Москва не глядит на своих жителей, а шлет товары во всю Русь; Петербург продает галстухи и перчатки своим чиновникам. Москва -- большой гостиный Авор; Петербург -- светлый магазин. Москва нужна Аля России; Аля Петербурга нужна Россия. В Москве редко встретишь гербовую пуговицу на фраке; в Петербурге нет фрака без гербовых пуговиц. Петербург Аюбит подтрунить наА Москвою, наА ее аляповатостью, неловкостью и безвкусием; Москва кольнет Петербург тем, что он человек продажный и не умеет говорить по-русски. В Петербурге, на Невском проспекте, гуляют в Ава часа Аюди, как будто сошедшие с журнальных модных картинок, выстав яемых в окна, Ааже старухи с такими узенькими талиями, что делается смешно; на гуляньях в Москве всегда попадется в самой середине модной толпы какая-нибудь матушка с платком на голове и уже совершенно без всякой талии. Сказал бы еще кое-что, но --

Аистанция огромного размера!..

\section{Dois caráteres (Mikhail Zagóskin)}

\section{Irmão e Irmã $\tilde{n}^{12}$}

Caso vocês não os conheçam pessoalmente, decerto já ouviram falar deles. Sem essa certeza eu não estaria aqui descrevendo esses dois caráteres, nos quais não há nada de significativo e especial a não ser certa estranha oposição, apesar de nos referirmos não a irmãos de criação ou primos, mas a irmãos de sangue, ou seja, nascidos de uma mesma mãe. A educação dada a ambos foi igual, pelo menos tiveram o mesmo professor; uma pessoa muito inteligente, um pouco severa, é verdade, porém imparcial e amiga de verdade. Quando começou a ensiná-los, o irmão era um bebê, enquanto a irmã já era uma jovem; o irmão vivia com ele em um quarto, enquanto a irmã vivia em seu próprio cômodo; dessa forma, entende-

12 O artigo Dois caracteres foi publicado pela primeira vez na revista Moskvitiánin, em 1841, parte 2, No 2. 
-se que o professor passava mais tempo com seu aluno do que com sua aluna, do que concluíram que ele amava mais o irmão, porém isso é uma completa calúnia. Mas não é essa a questão.

Já lhes contei que a irmã era bem mais velha que o irmão, e, portanto, não é de se admirar que na aparência eles fossem diferentes um do outro: ele é um rapaz jovem, enquanto ela é uma senhora; ele não tem sequer uma ruga na face, e ela, coitada, por mais que se maquie, avermelhe as bochechas ou pinte os cabelos, os cachos grisalhos aparecem mesmo assim por debaixo do chapéu da moda. O maninho tem aparência bela e jovial, arrumado, sempre em posição de sentido, esbelto, aprumado, com cinto apertado, dando ao corpo forma de um cálice, abotoado com todos os botões; a irmã, ao contrário, é uma senhora avantajada e corpulenta, mantém-se bastante desleixada, gosta de fazer caretas, não suporta nenhuma imposição, anda com roupa desabotoada e, como uma bela e mimada concubina do harém, fica se espreguiçando o dia todo em seus travesseiros de pluma de ganso. Entretanto, não podemos deixar de ser justos com ela: ela é mestre em escolher suas posições e dar a elas uma graciosidade singular. Conheço muitos que gostam bem menos dos movimentos corretos e das poses estéticas do irmão, do que da maneira descuidada e modos pouco europeus da irmã.

O irmão anda muito a pé, não tem medo do aperto e gosta de viver no alto: ele não se assusta com escadas, nem as de duzentos degraus. É difícil encontrar uma pessoa que aprecie tanto limpeza e asseio quanto ele. Da mesma forma ele gosta em excesso de uniformidade e simetria: caso um lado do colarinho de sua camisa estiver aparecendo meio vercho $k^{13}$ debaixo da gravata, podem ter certeza de que do outro lado não aparecerá nem um centímetro a mais ou a menos. Quando a velha moda de usar dois relógios voltar, seguida pelos extravagantes móveis Rococó, ele, sem dúvida alguma, será o primeiro a aparecer usando dois relógios, para que do lado esquerdo do seu colete esteja pendurada uma corrente com chave, assim como do lado direito. No geral ele é muito elegante e no inverno veste moda leve, possivelmente porque na Itália e na França ninguém use casacos de pele de urso. Mesmo com um frio intenso ele prefere deixar as orelhas congelarem a usar o nosso gorro russo junto com seu chapéu europeu arredondado.

A irmã não gosta de andar a pé nem de andar em carruagem puxada por dois cavalos a tal ponto que até mesmo à missa em sua paróquia não vai de outra forma a não ser em carruagem puxada por quatro cavalos. Ela decididamente não consegue viver no aperto; ela precisa de muito espaço, ou seja: de uma casa

13 Antiga unidade russa de medida equivalente a $4,4 \mathrm{~cm}$. 
diferenciada, cômodos grandes e altos, vastos serviços, e mais do que tudo, de um amplo pátio, mesmo que sujo, com um pequeno jardim no qual devem ser plantados, necessariamente, sabugueiro, lilás e acácia; assim como seu irmão, ela gosta de calçadas de granito, das maravilhosas pontes marginais de ferro fundido, das margens do rio revestidas de grama, jardins, rosas e até mesmo de hortas de repolho e batata. Basta dar uma olhada nela para ter certeza de seu completo ódio por qualquer uniformidade e simetria. Olhem para o adorno em sua cabeça. Que mistura! Que junção de cores vivas que não possuem entre si nenhuma harmonia! Que estranha combinação do velho com o novo! Sobre o adorno de pérolas dessa senhora russa estão presas flores de loja francesa; em meio a colares de pérolas pesados brilha um broche à nova moda Sevigne ${ }^{14}$; nas mãos, luvas longas de pelica; nos pés, botas pretas com bordas vermelhas; em um dos braços, um bracelete parisiense, em outro, uma pulseira com pedras preciosas, uma verdadeira casa de penhor. O que vocês acham? Apesar dessa variedade e falta de gosto, ninguém terá coragem de dizer que esse traje é de mau gosto; pode ser até que vocês gostem. Aliás, é preciso dizer que essa é a roupa para ficar em casa, pois quando ela sai, juro que é impossível diferenciá-la de uma francesa; só não exijam que ela, por conta da moda europeia, deixe congelar seu nariz e orelhas: isso ela não fará por nada, e, se estiver frio, vestirá imediatamente por cima de uma touca de tule, um gorrinho quente, e não sentirá vergonha alguma de, mesmo no mês de abril, sair para passear com um casaco de pele de raposa, apesar de haver em seu guarda-roupa abrigos e até mesmo casacos que ela encomendou diretamente de Paris.

Há pouco tempo o irmão conseguiu uma casa. Incomparavelmente mais rico do que a irmã, ele não é avarento, no entanto, é ponderado; já ela é uma grande governanta e está sempre sem dinheiro. O irmão não costuma dar festas com frequência, mas quando dá é realmente de causar inveja: com muito bom gosto, com luxo, em uma palavra: uma maravilha! A irmã é muito hospitaleira; é claro, ela nem sempre serve bem, e o vinho dela, vez ou outra, é servido com muito custo; por outro lado, o irmão convida para o almoço, mas em seguida tranca o portão e por mais que você toque a campainha, ele nunca atende; já a irmã está sempre de portas abertas! As portas dela, sem sino e portão, estão sempre escancaradas. O irmão é muito inteligente, enquanto a irmã é demasiadamente ingênua; ele é ponderado, frio e desde a manhã até a noite está ocupado; ela é bondosa, amável e fica o dia todo sem fazer nada. Ele aprecia o que é belo prazerosamente e não economiza com isso; ela se encanta com tudo que é incomum e quer possuir tudo

14 Broche oval com três pingentes. 
só que pelo valor mais barato possível. Pelo último item não há como julgá-la: de que modo ela poderia competir com o irmão! E eis o que é estranho: se ela mesma sente que não pode esbanjar dinheiro como o irmão, então por qual motivo quer que a divirtam, assim como divertem ao seu irmão? Pois ela é uma senhora russa e deveria conhecer o antigo provérbio: "vive-se de acordo com as posses". O irmão, assim como todas as pessoas ricas, gosta que o entretenham com novidades; entretanto, não faz pouco caso do antigo, quando é bom. A irmã não tolera nada que seja velho: sempre tem que ter algo novo. É tão leviana, que não dá nem para falar! Hoje ela gosta de uma coisa, amanhã de outra; por exemplo, certa vez ela colocou na cabeça que iria gostar do teatro francês até a morte e simplesmente perdeu o juízo. "Quero o teatro francês! Não posso viver sem o teatro francês!" Fez um escândalo e tanto! "Eu não me importo com dinheiro! Não me arrependerei de nada: colocarei até o meu último bem na casa de penhor, quero apenas o teatro francês!” E seja qual for o teatro francês a irmã se encanta: “Que perfeição! Que talento! Que canto harmônico! Simplesmente uma maravilha!" Ela vai então ver teatro francês uma vez, outra, uma terceira vez, e depois disso não aparece nunca mais! Claro que isso não era difícil de prever, porque a minha senhora é russa, e isso ela faz só para se gabar e fingir-se de francesa; mas o difícil é explicar como, segundo as palavras dela, o teatro russo pode ser tão ruim, e o teatro francês ser tão maravilhoso, a ponto dela se divertir só com ele! O que vocês acham disso? Chegava a ferir as pernas de seus lacaios de tanto enviá-los, todos os dias, atrás de bilhetes para o teatro russo, por outro lado, não queria sequer dar uma olhada no teatro francês; e que traquinagem; ela jurava a todos que não frequentava mais o teatro francês por não conseguir camarotes; mas há muitos diretores e é bem provável que o próprio diretor conseguisse um para ela.

O irmão é uma pessoa calada, não diz sequer uma palavra em vão; já a irmã é uma tagarela, Deus me livre! E se a conversa for sobre notícias, "se não gosta não ouça": o fulano casou, ciclano morreu e o terceiro subiu de classe; e se não aconteceu nada, então não interessa! E como depois disso não desculpar o irmão por ele às vezes fazer piadas de sua irmã mais velha? Porém, tenho certeza de que ele a ama e respeita de verdade, e a amaria e respeitaria ainda mais se a conhecesse mais de perto. Me esqueci de mencionar que eles sempre vivem separados. A irmã, é lógico, tem seus defeitos; mas em compensação é uma mulher tão cordial, hospitaleira e de bom coração, que, apesar de todas as suas estranhezas e caprichos, é impossível não amá-la. Posso dizer por mim mesmo: uma vez a conhecendo, de modo algum se quer ficar longe dela.

Tanto o irmão, quanto a irmã sofreram com grandes desgraças, só que nisso os fatos não tiveram nenhuma relação. $\mathrm{O}$ irmão sempre sofreu com a água, 
enquanto a irmã sofreu com o fogo. Certa vez ele se afundou nas águas, enquanto ela, umas quatro vezes, por pouco não morreu nas chamas; é verdade que, da última vez, ela mesma ateou fogo em sua própria casa; eu mesmo fui testemunha disso.

Vocês já sabem que ela é muito leviana e crédula; por exemplo, alguns gabarolas disseram a ela sabe deus o que sobre um monsieur, diabrete e desordeiro, que ele era amável, bondoso e educado! Minha senhora ficou maluca, delirou por ele dia e noite. Esses rumores chegaram até ele. É preciso dizer que esse monsieur é uma pessoa cheia de amor-próprio e se considera o melhor de todos. Eis que ele colocou na cabeça que a nossa senhora se apaixonou por ele completamente: já haviam dito a ele que se tratava de uma mulher rica, de posse; dessa forma, não é de se admirar que os olhos desse monsieur brilharam quando o assunto foi a riqueza dela: "Espere!" - disse ele; "A visitarei! Não é perto, mas eu tenho um bom cocheiro, chegarei logo. Ela, é claro, correrá ao meu encontro e se atirará em meu pescoço; prometerei mundos e fundos, farei vários gracejos e me derreterei e direi, ao me despedir: Senhora! Eu estou feliz com você! Minha espera foi recompensada, eu a amo! E assim por diante." Mas nada disso! O monsieur na verdade chegou ao pátio dela rápido demais, aguardou, aguardou e não a encontrou, então ele, sem ser anunciado, foi para o cômodo. Meu Deus! Como isso enfureceu a senhora. "Como você se atreve? Quem lhe deu permissão? Por um acaso eu lhe convidei? Ah, seu insolente!... Fora daqui, já!” Qualquer outro ficaria envergonhado, mas esse monsieur era um cabeça-dura; ele já estava acostumado a perambular por propriedades alheias. Apesar do aborrecimento pelo fato de o receberem com tanta indelicadeza, ele, mesmo assim, decidiu hospedar-se por lá. Vestiu um roupão, ajeitou seu gorro e se acomodou na casa dela como se lá fosse sua própria casa. "Já que é assim, - disse a senhora, meu amigo, eu o enxotarei!" - Ela então chamou a estaroste Vassilíssa e a ordenou municiar todas as criadas com o que tivesse à mão: vassoura, atiçador, e assim, ela mesma ateou fogo em sua própria casa e se escondeu. $\mathrm{O}$ monsieur não apreciava nem um pouco o nosso inverno russo, e com o fogo da mesma forma ele também não se deu. Eis que quando ele percebeu que o queriam assar vivo saiu correndo! E então o atacaram dos esconderijos! Ele até tentou mostrar as garras; em vão! Não deixaram o rapaz voltar a si! Monsieur, pernas pra que te quero! E no seu encalço, no encalço, apenas a cabeça ficou intacta, já os quadris estavam tão machucados que ele, de maneira alguma conseguiria se arrastar até sua casa, se as pessoas de bom coração não o tivessem levado de trenó. Sem dúvida alguma, essa atitude heroica e a abnegação de nossa senhora foram descritos em prosa e verso em periódicos, mas ela, minha flor, de modo algum se orgulhava disso, e sequer guardava rancor, tanto que, logo após o ocorrido que a fez passar o monsieur, ela lhe enviou um cartão e ordenou que 
buscassem informações sobre a sua saúde. Tudo isso é extremamente elogiável, mas tem uma coisa pela qual não dá para elogiá-la: já há certo tempo, parece-me que ela, por compaixão a esse desordeiro, arruinou-se completamente e o pior, novamente se apaixonou por ele, ou fingiu estar apaixonada, sabe lá Deus! Por mais que dessa vez ela não faça dengo, já não vai fazer o monsieur de bobo outra vez! Ele deve pensar: "Não, madame, estás brincando! Chega de lançar olhares, nós a conhecemos! O quê, novamente passei a ser o queridinho? Sou uma pessoa instruída, eu mesmo sou educado e educo todos e assim por diante."; mas apenas experimente se meter! Você vai ser considerado um atiçador.

Eu poderia continuar ainda mais a comparação do irmão com a irmã mas, com certeza, vocês já devem saber de quem estamos falando e podem continuar essa comparação vocês mesmos. Mas, se ainda não descobriram quem é o irmão e quem é a irmã, então eu terei de dizer-lhes quem são eles... Ou melhor não! ...Tenho medo! Eles são pessoas inteligentes e bondosas e acho que não ficarão zangados com a brincadeira mas, sabe-se lá, pode ser que se ofendam se eu os chamar pelos seus respectivos nomes.

\section{«вва характера»}

\section{Брат и сестра (Михаим Загоскин)}

Если вы их не знаете мично, то уж, верно, знакомы с ними понаслышке: без этой уверенности я бы не стал вам описывать два характера, в которых нет ничего особенно замечательного, кроме какой-то странной противоположности межАу собой, несмотря на то, что эти брат и сестра - не сводные, не Авоюродные, а еАинокровные, то есть: родились от оАной и той же матери. Воспитание получили они также одинаковое - по крайней мере, учитель был у них один: человек очень умный, немного крутой - это правАа, но зато совершенно беспристрастный и истинный их Аруг. КогАа он взял их на выучку, брат был ребенком, а сестра уж девица взрослая; брат жил с ним в одной комнате, а сестра на своей половине, - так, разумеется, он был чаще со своим учеником, чем со своей ученицей; а из этого и заключили, что он больше Аюбил брата, чем сестру - только это совершенная клевета. $\triangle а$ дело не о том. 
Я уж сказац вам, что сестра гораздо старее годами своего брата, следовательно, вовсе не удивительно, что по наружности они не походят Аруг на Аруга: он малый молодой, она пожилая барыня; у него нет ни одной морщины на Аице, а у нее, бедняжки - как она ни белится, ни румянится, как ни красит волосы, - а все седые Аоконы так из-под модной шляпки и выглядывают. Братец смотрит молодцом, выправлен, всегда навытяжке, строен, подборист, затянут в рюмочку и застегнут на все пуговицы; сестра, напротив, плотная, Аородная барыня, держит себя весьма нерадиво, Аюбит покрив $я$ ться, не терпит никакого принуждения, ходит нараспашку и, как избалованная красавица гарема, нежится с утра до вечера на своих пуховых подушках. Нельзя, однако ж, не отдать ей справедливости: она большая мастерица выбирать свои положения и придавать им какую-то особенную грациозность. Я знаю многих, которым правильные Авижения и эстетические позы брата гораздо менее нравятся, чем небрежная манера и вовсе не европейские ухватки сестры.

Брат много ходит пешком, не боится тесноты и Аюбит жить высоко: его не испугает Аестница и в двести ступеней. Трудно найти человека, который уважал бы более его чистоту и опрятность. Он также чрезвычайно Аюбит еАинообразие и симметрию: если оАин воротничок его рубашки выпущен из-под галстуха на полвершка, так уж будьте уверены, что Аругой ни на волосок не выставится ни больше, ни меньше этого. КогАа старая мода носить по Авое часов вернется к нам вслеА за вычурной мебелью Rococo, то, без всякого сомнения, он первый явится с Авумя часами, А^я того чтоб на мевой стороне его жилета висела цепочка с ключиком, так же как и на правой. Вообще, он большой щеголь, и зимой одевается отлично Аегко, вероятно, потому, что в Италии и Франции никто не носит медвежьих шуб. В самый сильный холод он скорее решится отморозить себе уши, чем надеть вместо своей круглой европейской шАяпы нашу теплую русскую шапку.

Сестра ходить пешком не охотница и до того не Аюбит ездить парою в карете, что даже к обедне в свой приход не поедет иначе, как четверней. Жить в тесноте она решительно не может; ей наАобен простор, то есть: особый Аом, высокие, большие комнаты, обширные службы, а пуще всего хотя грязный, Аа просторный Авор с небольшим садиком, в котором должны расти непременно: бузина, сирень и акации; точно так же, как ее брат Аюбит гранитные тротуары, великолепные набережные и чугунные мосты, она Аюбит берега реки, обросшие травою, сады, розы и даже огороды с капустою и картофелем. Стоит только на нее взглянуть, чтобы увериться в ее совершенной ненависти ко всякому единообразию и симметрии. Посмотрите 
на ее головной убор - какая пестрота! какое смешение ярких цветов, не имеющих меж собой никакой гармонии! какое странное сближение старого с новым! НаА жемчужной поднизью старинной русской боярыни приколоты цветы из французского магазина; посреди тяжелых ожерельев и монист блестит новомодное севинье; на руках Алинные майковые перчатки; на ногах черные коты с красною оторочкою; на одной руке парижский браслет, на Аругой запястье, осыпанное Арагоценными каменьями, - ну точно меняльная Аавка! - И что ж вы думаете?.. Несмотря на эту пестроту и безвкусие, у вас язык не повернется сказать, что этот наряд Аурен, - может быть, он вам даже и понравится. Впрочем, надобно вам сказать, что это наряд Аомашний, а когда она выезжает, так, уверяю вас, вы не распознаете ее от француженки; - только не требуйте от нее, чтобы она раАи европейства отморозила себе нос или уши: этого она ни за что не слелает, и, если холодно, так наденет непременно сверх тюлевого чепца теплую шапочку и вовсе не постылится Ааже в апреле месяце выйти погулять в салопе на Аисьем меху, несмотря на то, что в ее гардеробе есть и клоки, и манто, и Ааже бурнус, который она выписа^а прямехонько из Парижа.

Брат недавно завелся домом, а несравненно богаче сестры; он не скуп, однако ж, расчетлив; она большая экономка, и вечно без денег. Брат не часто дает пиры, а уж если Ааст, так истинно на славу: с большим вкусом, с роскошью, одним словом - все прекрасно. Сестра большая хлебосолка - конечно, она не всегда хорошо накормит, и вино у нее подчас бывает с грехом пополам; но зато брат дает обеА, да тотчас и вороты на запор - как ни звони в колокольчик, а все Аома нет да нет, а к сестре каждый день милости просим! У ней двери без колокольчика и вороты всегда настежь. Брат очень умен, а сестра чрезвычайно простодушна; он рассудителен, холоден и с утра до вечера занят Аелом; она Аобра, приветлива и целый Аень ничего не делает. Он охотно Аюбуется всем прекрасным и не жалеет на это Аенег; она в восторге от всего необыкновенного и хочет все иметь; но только как можно подешевле. За последнее осуждать ее нельзя: где ей тягаться за братом! Аа вот что странно: уж если она сама чувствует, что не может сорить деньгами, как ее братец, так зачем же требует, чтоб ее забавляли точно так же, как забавцяют ее брата? Ведь она русская барыня и должна бы, кажется, знать старинную пословицу: «По одежке тяни ножки». - Брат, как и все богатые Аюди, Аюбит, чтоб его тешили новостями; однако ж, не пренебрегает старым, когда оно хорошо. Сестра не может терпеть ничего старого: Аавай ей каждый день что-нибудь новенькое - такая ветреница, что и сказать нельзя! Сегодня ей нравится одно, завтра другое; Аа вот, хоть, например, пришло ей однажАы в 
голову, что она до смерти Аюбит французский театр - ну просто повредицась на этом пункте. «Хочу французский театр! - Не могу жить без французского театра!» - Шумит, да и только! - «Я, дескать, за казну не постою! Ничего не пожалею: последнее именье в момбарА заложу - давайте мне только французский театр!» - Вот, откуда ни возьмись, - явился французский театр - сестрица в восторге! - «Что за совершенство! - Какие таланты!.. Как склаАно поют!.. Ну, чудо да и только!» - Вот едет она во французский театр: раз, Аругой, третий, - а там глядь-погляАь, и слеА просты ! - Конечно, это можно было предвидеть, потому что моя барыня в Ауше русская и только так - раАи хвастовства - прикидывается француженкой; но вот что трудно изъяснить: по ее словам, русский театр очень плох, а французский чудо - им только она душу себе и отводит! - И что ж вы думаете? - С ног сбила своих макеев, посылая их каждый день за билетами в русский театр, а во французский и заглянуть не хочет; да еще такая проказница - уверяет всех, будто бы не езАит во французский театр оттого, что нельзя достать Аожи; а их бери сколько хочешь; я это знаю наверное - от самого Аиректора.

Брат человек молчаливый, слова не скажет даром; сестра такая болтунья, что не приведи господи! А уж если дело пойдет на новости, так что твое «не Аюбо - не слушай»: того женили, Аругого уморили, третьего произвели в чин; а ничего не бывало - все вздор! - Ну как после этого не извинишь брата, что он иногАа наА своей старшей сестрой подшучивает? Хоть, впрочем, я уверен, что он ее истинно мюбит и уважает, и еще бы мюбил и уважац больше, если бы знал ее покороче. Я забыл вам сказать, что они всегда живут розно. Сестра, конечно, имеет свои недостатки; но зато такая радушная, гостеприимная и добросердечная женщина, что, несмотря на все ее странности и причуды, ее нельзя не полюбить. Я знаю это по себе: стоит только раз с нею познакомиться, а там уж ни за что не захочешь расстаться.

С братом и с сестрой во время их жизни случались также большие несчастья; только и в этом нет у них никакого сходства. Брат всегда страАаА от воды, а сестра от огня. Он однажды совсем было утонул, а ее раза четыре чуть живую из полымя выхватывали; правда, в последний раз она сама зажгла свой АОм, и вот по какому случаю: я могу вам рассказать об этом как очевидец.

Вы уж знаете, что она большая ветреница и очень мегковерна; вот какие-то хвастунишки наговорили ей и бог знает что об одном мусье, отьяв Аенном сорванце и буяне - и миц-то он, и хорош, и Аюбезен! Моя барыня с ума сошла, бредит им день и ночь. Аошли и до него об этом слухи. Налобно вам сказать, что этот мусье человек пресамолюбивый и считает себя 
мучше всех на свете. Вот он и вообразиц, что наша барыня влюбилась в него по уши: ему же сказали, что она женщина богатая, что у нее всего много; так не Аиво, что у этого мусье глаза разгорелись на ее богатство: «Постой, сказац он, - отправ юсь к ней в гости - оно не близко, Аа у меня Аихой ямщик, разом доставит. Она, разумеется, выбежит навстречу, кинется мне на шею; я наговорю ей с три короба всяких комплиментов, облуплю как Аипку и скажу ей на прощанье: Барыня! я доволен тобою! 'Ты оправдаца мое ожидание - я Аюблю тебя! - и прочее, и прочее». - Аа, как бы не так! - Вот мусье в самом

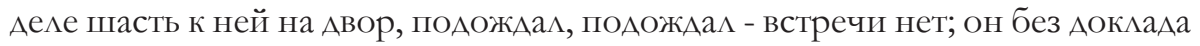
и в комнату. - Батюшки! как взбелени ась моя барыня. - «Да как ты сме $?$ ? - Аа кто тебе позволиц? - Аа разве я звала тебя в гости?.. Ах ты, наглец!.. Сейчас

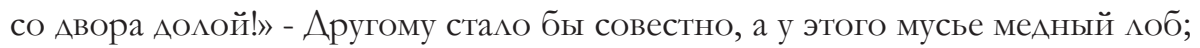
да он же и привык по чужим дворам шататься. Хоть и досаАно было, что его приняли так неласково, а он все-таки решился у нее погостить, нале халат, натянул колпак и расположился у нее, как в своем доме. - «Так-то, сказала барыня, - так я же тебя, Аружок, выкурю!» - Она призвала старостиху Василису, приказала ей снарядить всех дворовых Аевок чем ни попало: кого метлой, кого кочергою, а сама подсунула в дом огоньку и притаилась за углом. Мусье очень не жалует нашего русского мороза, Аа ведь и огонь-то не свой брат. Вот как он догаАался, что его хотят живого изжарить - скорее вон! А тут из засады на него и высыпали, да ну-ка его обрабатывать! - Он было огрызаться, - куда! Не Аали молодцу образумиться! Мусье Аавай бог ноги! - А его вАогонку-то, вдогонку, - только одна голова и уцелела, а бока так отломали, что он, сердечный, никак бы до дому не Аотащился, если б добрые Аюди его на салазках не Аовезли. Разумеется, этот геройский поступок и самоотвержение нашей барыни расхвали и в газетах, описали и в прозе, и в стихах, но она, моя голубушка, вовсе этим не возгордилась, и даже так была не зцопамятна, что очень скоро после обиды, которую ей слелац этот мусье, отправила к нему визитную карточку и велела спросить о здоровье. - Все это весьма похвально; а вот за что нельзя ее похвалить: Аавно $и$, кажется, она,

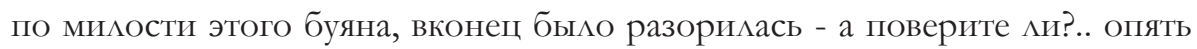
уж в него влюблена или прикидывается, что мь, в ююбленною - бог ее знает! Только как она теперь ни кокетничай, а уж мусье Аругой раз на бобах не проведешь! - Чай, он думает про себя: «Нет, madame, шутишь! Полно глазкито Аелать: знаем мы тебя! - Что? По-прежнему стал миленьким? - И человек-то я образованный, и сам-то я просвещен, и Аругих всех просвещаю - и то и се; а попробуй - сунься! Так ты опять ухватом иль кочергою!» 
Я мог бы еще продолжать это сравнение брата с сестрою, Аа, верно, уж вы знаете, о ком речь идет, так можете и сами это сделать. А если вы еще не отгадали, кто этот брат и кто эта сестра, так, пожалуй, я вам скажу, кто они... Аа нет!.. боюсь! Они Аюди умные, добрые и, кажется, за шутку гневаться не станут; а ведь, бог знает, может быть, и рассердятся, если я назову их по имени.

\section{Referências}

IUSSÚPOV, K. Diálogo das capitais no movimento histórico (Dialóg stolits v istorítcheskom dvijénii). In: Pro et Contra Moscou - Petersburgo (Pro ET Contra Moskvá - Peterburg). Moscou: RGKHI 2000.

TOPOROV, Vladimir. Petersburgo e o texto de São Petersburgo da literatura russa (Peterburg i peterbúrgskii tekst rússkoi literatury). In: Texto petersburguês da literatura russa (Peterbúrgskii telest rússkoi literatury), São Petersburgo: Iskusstvo, 2003. . Mito, ritual, simbolo e imagem, (Mif, Ritual, Simvol, Óbraz), Moscou, 1993.

. O texto de São Petersburgo da literatura russa (Peterbúrgskii tekst rússkoi literatury), São Petersburgo, 2003.

Sobre a estrutura do romance de Dostoiévski em relação aos esquemas arcaicos do pensamento mitológico (O struktúre romana Dostoiévskogo v sviaí s arkhaítcheskimi skhiémami mifologuítcheskogo mychliénia). In: Mito, ritual, símbolo, imagem (Mif, ritual, simvol, óbraæ). Moscou, 1995. p. 193-258. 